\title{
Genetic Association Estimates Using Third and Fourth Degree Statistics in Early Segregating Generations of Cowpea
}

\author{
H.B. Dinesh", K.P. Viswanatha, H.C. Lohithaswa, R. Pavan and Poonam Singh \\ Department of Genetics and Plant Breeding, University of Agricultural Sciences, GKVK, \\ Bangalore 560 065, Karnataka, India \\ *Corresponding author
}

\begin{abstract}
A B S T R A C T
Correlation and presence of genetic interactions was studied using $\mathrm{F}_{2}$ and $\mathrm{F}_{3}$ generations in two cowpea crosses for yield and its component traits. Most of the characters studied were

Keywords

Correlation,

Cowpea, Gene

interaction,

Kurtosis, Skewness

Article Info

Accepted:

10 December 2017

Available Online:

10 January 2018 positively skewed and were being governed by several genes indicating quantitative inheritance. Variance, skewness and kurtosis have also indicated that homozygosity has increased from the generation to generation in cowpea crosses. Cross A (C-152 $\times$ V-16) was found better than crossB $(\mathrm{C}-152 \times \mathrm{V}-57817)$ in providing high yielding segregants displaying parental diversity. Number of branches and 100 seed weight were positively skewed in both crosses and in both the generation. Number of seeds per pod and seed yield per plant was positively skewed in cross A while number of pods per plant was positively skewed in cross B. which is a true indication of complementary gene interaction with other genes governing these characters. Whereas, plant height was negatively skewed in both cross this indicates duplicate gene interaction. Yield increase is possible by following rigid selection for yield and its component characters. A shift in correlation coefficients between the generations was recorded which is likely to be attributed to difference in gene complementation of linkage blocks and an indication of unstable nature of breeding population.
\end{abstract}

\section{Introduction}

Cowpea [Vignaunguiculata (L.) Walp., Fabaceae $(2 n=2 x=22)]$ is grown as one of the most important widely adapted, stress tolerant grain legume, vegetable and fodder crop in tropical and sub-tropical regions of Africa, Asia, Nigeria and America (Ehlers and Hall, 1997; Singh et al., 1997).Productivity of cowpea compared to cereals is very low. Hence, productivity can be increased by suitable breeding programmes. But, progress in breeding programme depends on amount of variability created during hybridization. First and second degree statistics viz., range, variance and standard error were commonly used to assess the variability for yield. But these are not sufficient in identifying plants with desirable expression of traits under selection. As yield is a complex trait, which is influenced by many other important yield contributing traits controlled by polygenes and also environmental factors. The information on frequency distribution of different traits 
will also help in identifying plants with desirable expression of traits under selection (Preetha and Raveendren 2008). Therefore, improvement in yield could be brought about by effecting indirect selection procedures by considering other component characters, which are highly heritable and show strong correlation with yield. With this points in view, the present study was aimed at studying the genetic association of different traits using third and fourth degree statistics in early segregating generations of cowpea.

\section{Materials and Methods}

The study was conducted at Department of Genetics and Plant Breeding, College of Agriculture, V. C. Farm, Mandya, University of Agricultural Sciences (UAS), Bengaluru, India. Materials used for this study consisted of $\mathrm{F}_{2}$ and $\mathrm{F}_{3}$ generations from two crosses of cowpea namely C-152 $\times \mathrm{V}-16$ (Cross A) and C-152 $\times$ V-57817 (Cross B).

The early segregating generations, $\mathrm{F}_{2}$ and $\mathrm{F}_{3}$ were raised by selfing. These crosses were performed in order to combine high yielding ability of C-152 with Bacterial Leaf Blight resistant variety $\mathrm{V}-16$ and cowpea mosaic virus (CpMV) resistant variety V-57817, which were released from Indian Agricultural Research Institute, New Delhi. Observations were recorded at physiological maturity on the yield and its attributes like, plant height $(\mathrm{cm})$, number of branches per plant, number of pods per plant, number of seeds per pod, 100 seeds weight (gm) and seed yield per plant (gm).

The association between yield and its associated characters was worked out as a simple phenotypic correlation coefficient following the method suggested by Pearson (1895). Skewness $\left(\mathrm{K}_{3}\right)$, the third degree statistics and kurtosis $\left(\mathrm{K}_{4}\right)$, the fourth degree statistics were estimated (Snedecor and Cochron, 1967) using PAST statistical software (Hammer et al., 2001) to understand the nature of distribution of different traits.

$$
\begin{aligned}
& \mathrm{K} 3=\frac{\mathrm{n}}{(\mathrm{n}-1)(\mathrm{n}-2)} \sum_{\mathrm{j}=1}^{\mathrm{n}}\left(\mathrm{Y}_{\mathrm{j}}-\overline{\mathrm{Y}}\right)^{3} \\
& \mathrm{~K}_{4}=\frac{\mathrm{n}}{(\mathrm{n}-1)(\mathrm{n}-2)(\mathrm{N}-3)}\left\{(\mathrm{n}-1) \sum_{\mathrm{j}=1}^{\mathrm{n}}\left(\mathrm{Y}_{\mathrm{j}}-\overline{\mathrm{Y}}\right) 4-\frac{3(\mathrm{n}-1)}{\mathrm{n}}\left[\sum_{\mathrm{j}=1}^{\mathrm{n}}\left(\mathrm{Y}_{\mathrm{j}}-\mathrm{Y}\right)^{2}\right]\right\}
\end{aligned}
$$

Where, n-sample size, $\mathrm{Yj}$ - observational value of $j^{\text {th }}$ sample, $Y$-sample mean

For a normal distribution, skewness is equal to zero in absence of gene interaction; it is greater and smaller than zero in presence of average complementary and duplicate interactions respectively. Also, gene interactions can be detected by studying fourth degree statistics, kurtosis which is always negative or near to zero in absence of gene interaction and positive only in presence of gene interaction (Choo and Reinbergs, 2008). Three types of kurtosis are recognized based on the kurtosis value which depends on distribution curve (Robson, 1956).

If kurtosis value $=0=$ Normal curve $=$ Mesokurtic,

If kurtosis value $>0=$ Leaping curve $=$ Leptokurtic and

If kurtosis value $<0=$ Flat curve $=$ Platykurtic

The standard error for coefficient of skewness and kurtosis were estimated as per Fisher (1950) as follows;

$$
\begin{aligned}
& \text { SEK 3 }=\sqrt{\frac{6 n(n-1)}{(n-2)(n+1)(n+3)}} \\
& \text { SEK } 4=\sqrt{\frac{24(n-1)^{2}}{(n-3)(n-2)(n+5)(n+3)}}
\end{aligned}
$$


Frequency distribution for each trait significantly deviated from zero $(\mathrm{P}<0.05)$ probability level if that value was greater than twice of its standard error.

\section{Results and Discussion}

The study of distribution using skewness and kurtosis provides information about nature of gene action and number of genes controlling the traits (Samak et al., 2011; Nachimuthu et al., 2014). Positive skewness is associated with complementary gene action while negative skewness is associated with duplicate (additive $\times$ additive) gene interactions. Kurtosis is negative or close to zero (platykurtic) in absence of gene interaction and positive in presence of gene interaction (leptokurtic) (Nachimuthu et al., 2014). Studies on gene interactions are needed to increase the efficiency of selection in breeding program.

In $\mathrm{F}_{2}$ generation, all the traits viz., number of branches, number of seeds per pod, 100 seed weight and seed yield per plant were positively skewed except plant height was negatively skewed in both the crosses. But, number of pods per plant was negatively skewed in cross A and positively skewed crosses B (Table 1).

In $\mathrm{F}_{3}$ generation, all the traits viz., plant height, number of branches, number of pods per plant, number of seeds per pod, 100 seed weight and seed yield per plant were positively skewed in cross-A and cross-B except number of seeds per pod and seed yield per plant were negatively skewed in cross B (Table 2).

Distribution curves of seed yield in $\mathrm{F}_{2}$ and $\mathrm{F}_{3}$ generation of cross- $\mathrm{A}$ and cross- $\mathrm{B}$ are presented in Figure 1. Distribution curve of $F_{2}$ generation (Table 1) showed that all the traits in cross $\mathrm{A}$ and cross $\mathrm{B}$ were platykurtic except number of branches in cross $B$ was leptokurtic. In $\mathrm{F}_{3}$ generation, all the traits showed leptokurtic distribution in cross A except number of branches and 100 seed weight showed platykurtic distribution (Table 2 ). In cross B, except number of pods per plant showed platykurtic distribution while other traits showed leptokurtic distribution.

Traits viz., number of branches and 100 seed weight were positively skewed in both crosses and in both the generation. Number of seeds per pod and seed yield per plant was positively skewed in cross A while number of pods per plant was positively skewed in cross B.

This positively skewed distribution is an indication of complementary gene interaction. Whereas, plant height was negatively skewed in both cross and number of seeds per pod and seed yield per plant was negatively skewed in $\mathrm{F}_{3}$ generation of cross $\mathrm{B}$ which indicates duplicate gene interaction. This result is in agreement with the earlier studies (Sulistyowati, 2015).

Selection intensity and progress in improving population performance may be greater under complementary interactions than under duplicate interactions (Ajay et al., 2012). For all the above traits with duplicate gene action rapid genetic gain could be observed under mild selection using existing variability. Whereas, for traits with complementary gene action selection has to be strict for enhanced genetic gain which is in agreement with the earlier studies (Samak et al., 2011).

Positive coefficient of kurtosis for above mentioned traits indicates the presence of gene interaction and further it also indicates that these traits are governed by fewer numbers of dominant genes with majority having increasing effect (Nandini, et al., 2017). The variation recorded in seed yield, coefficient of skewness and kurtosis (Table 1 and 2) has decreased in $F_{2}$ over $F_{3}$ in both the crosses. 
Table.1 Skewness, kurtosis and variance for yield and its traits in $\mathrm{F}_{2}$ generation of two crosses of cowpea

\begin{tabular}{|c|l|c|c|c|c|c|c|}
\hline \multirow{2}{*}{$\begin{array}{c}\text { S. } \\
\text { No }\end{array}$} & \multicolumn{2}{|c|}{ Traits } & \multicolumn{2}{|c|}{ Variance } & \multicolumn{2}{c|}{ Skewness } & \multicolumn{2}{c|}{ Kurtosis } \\
\hline $\mathbf{1}$ & Plant height $\mathbf{( c m )}$ & 167.84 & 140.74 & -0.11 & -0.03 & -0.53 & -0.44 \\
\hline $\mathbf{2}$ & Number of branches & 2.99 & 2.13 & 0.17 & 0.49 & -0.27 & 0.02 \\
\hline $\mathbf{3}$ & Number pods per plant & 62.12 & 53.09 & -0.03 & 0.13 & -0.65 & -0.78 \\
\hline $\mathbf{4}$ & Number seeds per pod & 1.73 & 4.98 & 0.06 & 0.19 & -0.66 & -0.46 \\
\hline $\mathbf{5}$ & 100 seed weight & 7.23 & 6.48 & 0.37 & 0.26 & -0.29 & -0.64 \\
\hline $\mathbf{6}$ & Seed yield per plant & 104.00 & 87.43 & 0.44 & 0.51 & -0.50 & -0.42 \\
\hline
\end{tabular}

Note: Cross A: C-152 × V-16 Cross B: C-152 × V-57817

Table.2 Skewness, kurtosis and variance for yield and its traits in

$\mathrm{F}_{3}$ generation of two crosses of cowpea

\begin{tabular}{|c|l|c|c|c|c|c|c|}
\hline \multirow{2}{*}{$\begin{array}{c}\text { SI. } \\
\text { No }\end{array}$} & \multicolumn{2}{|c|}{ Traits } & \multicolumn{2}{c|}{ Variance } & \multicolumn{2}{c|}{ Skewness } & \multicolumn{2}{c|}{ Kurtosis } \\
\cline { 3 - 8 } & Cross A & Cross B & Cross A & Cross B & Cross A & Cross B \\
\hline $\mathbf{1}$ & Plant height (cm) & 21.46 & 100.07 & 0.67 & 0.96 & 1.29 & 1.46 \\
\hline $\mathbf{2}$ & Number of branches & 0.33 & 0.71 & 0.01 & 0.30 & -0.15 & 0.26 \\
\hline $\mathbf{3}$ & Number pods per plant & 7.56 & 15.54 & 0.83 & 0.18 & 0.73 & -0.23 \\
\hline $\mathbf{4}$ & Number seeds per pod & 1.53 & 2.00 & 0.54 & -0.39 & 1.13 & 0.65 \\
\hline $\mathbf{5}$ & 100 seed weight & 0.58 & 15.80 & 0.04 & 11.21 & -0.51 & 134.98 \\
\hline $\mathbf{6}$ & Seed yield per plant & 4.25 & 7.55 & 0.30 & -0.15 & 0.50 & 0.70 \\
\hline
\end{tabular}

Note: Cross A: C-152 × V-16 Cross B: C-152 × V-57817

Table.3 Correlation coefficient matrix among yield related characters in

$\mathrm{F}_{2}$ generation of two crosses of cowpea

\begin{tabular}{|c|c|c|c|c|c|c|c|}
\hline Characters & Crosses & $\begin{array}{l}\text { Plant } \\
\text { height }\end{array}$ & $\begin{array}{c}\text { Number } \\
\text { of } \\
\text { branches }\end{array}$ & $\begin{array}{c}\text { Number } \\
\text { pods per } \\
\text { plant }\end{array}$ & $\begin{array}{c}\text { Number } \\
\text { Seeds per } \\
\text { pod }\end{array}$ & $\begin{array}{c}100 \text { seed } \\
\text { weight }\end{array}$ & $\begin{array}{l}\text { Seed yield } \\
\text { per plant }\end{array}$ \\
\hline \multirow{2}{*}{$\begin{array}{l}\text { Plant height } \\
\text { (cm) }\end{array}$} & A & 1.000 & $0.340^{* * *}$ & 0.086 & 0.073 & $0.153^{*}$ & 0.033 \\
\hline & B & 1.000 & $0.818^{* *}$ & -0.002 & 0.052 & 0.049 & -0.081 \\
\hline \multirow{2}{*}{$\begin{array}{l}\text { Number of } \\
\text { branches }\end{array}$} & A & & 1.000 & -0.022 & -0.056 & $0.225^{* *}$ & $0.144^{*}$ \\
\hline & B & & 1.000 & -0.011 & 0.044 & 0.039 & -0.129 \\
\hline \multirow{2}{*}{$\begin{array}{l}\text { Number pods } \\
\text { per plant }\end{array}$} & A & & & 1.000 & 0.058 & -0.009 & -0.023 \\
\hline & B & & & 1.000 & 0.105 & -0.044 & -0.022 \\
\hline \multirow{2}{*}{$\begin{array}{l}\text { Number Seeds } \\
\text { per pod }\end{array}$} & A & & & & 1.000 & $0.131^{*}$ & -0.069 \\
\hline & B & & & & 1.000 & -0.051 & 0.091 \\
\hline \multirow{2}{*}{$\begin{array}{l}100 \text { seed } \\
\text { weight }\end{array}$} & A & & & & & 1.000 & 0.025 \\
\hline & B & & & & & 1.000 & $-0.190^{* *}$ \\
\hline \multirow{2}{*}{$\begin{array}{l}\text { Seed yield per } \\
\text { plant }\end{array}$} & A & & & & & & 1.000 \\
\hline & B & & & & & & 1.000 \\
\hline
\end{tabular}

Note: Cross A: C-152 × V-16 Cross B: C-152 × V-57817 
Table.4 Correlation coefficient matrix among yield related characters in $\mathrm{F}_{3}$ generation of two crosses of cowpea

\begin{tabular}{|l|c|c|c|c|c|c|c|}
\hline Characters & Crosses & $\begin{array}{c}\text { Plant } \\
\text { height }\end{array}$ & $\begin{array}{c}\text { Number } \\
\text { of } \\
\text { branches }\end{array}$ & $\begin{array}{c}\text { Number } \\
\text { pods per } \\
\text { plant }\end{array}$ & $\begin{array}{c}\text { Number } \\
\text { Seeds } \\
\text { per pod }\end{array}$ & $\begin{array}{c}100 \text { seed } \\
\text { weight }\end{array}$ & $\begin{array}{c}\text { Seed } \\
\text { yield per } \\
\text { plant }\end{array}$ \\
\hline $\begin{array}{l}\text { Plant height } \\
\text { (cm) }\end{array}$ & A & 1.000 & $0.193^{* * *}$ & -0.006 & 0.021 & $0.205^{* * *}$ & -0.021 \\
\hline $\begin{array}{l}\text { Number of } \\
\text { branches }\end{array}$ & B & 1.000 & 0.080 & -0.066 & -0.020 & 0.000 & -0.052 \\
\hline $\begin{array}{l}\text { Number pods } \\
\text { per plant }\end{array}$ & B & & 1.000 & 0.064 & -0.035 & 0.011 & -0.027 \\
\hline $\begin{array}{l}\text { Number Seeds } \\
\text { per pod }\end{array}$ & B & & 1.000 & 0.081 & 0.002 & 0.095 & -0.001 \\
\hline 100 seed & B & & & 1.000 & 0.01 & 0.037 & 0.056 \\
\hline weight & A & & & 1.000 & $0.134^{*}$ & 0.044 & 0.032 \\
\hline $\begin{array}{l}\text { Seed yield per } \\
\text { plant }\end{array}$ & $\mathrm{B}$ & & & & 1.000 & $0.238^{* * *}$ & 0.158 \\
\hline
\end{tabular}

Note: Cross A: C-152 × V-16 Cross B: C-152 × V-57817

Fig.1 Normality distribution of seed yield in $\mathrm{F}_{2}$ and $\mathrm{F}_{3}$ generations of two cowpea crosses
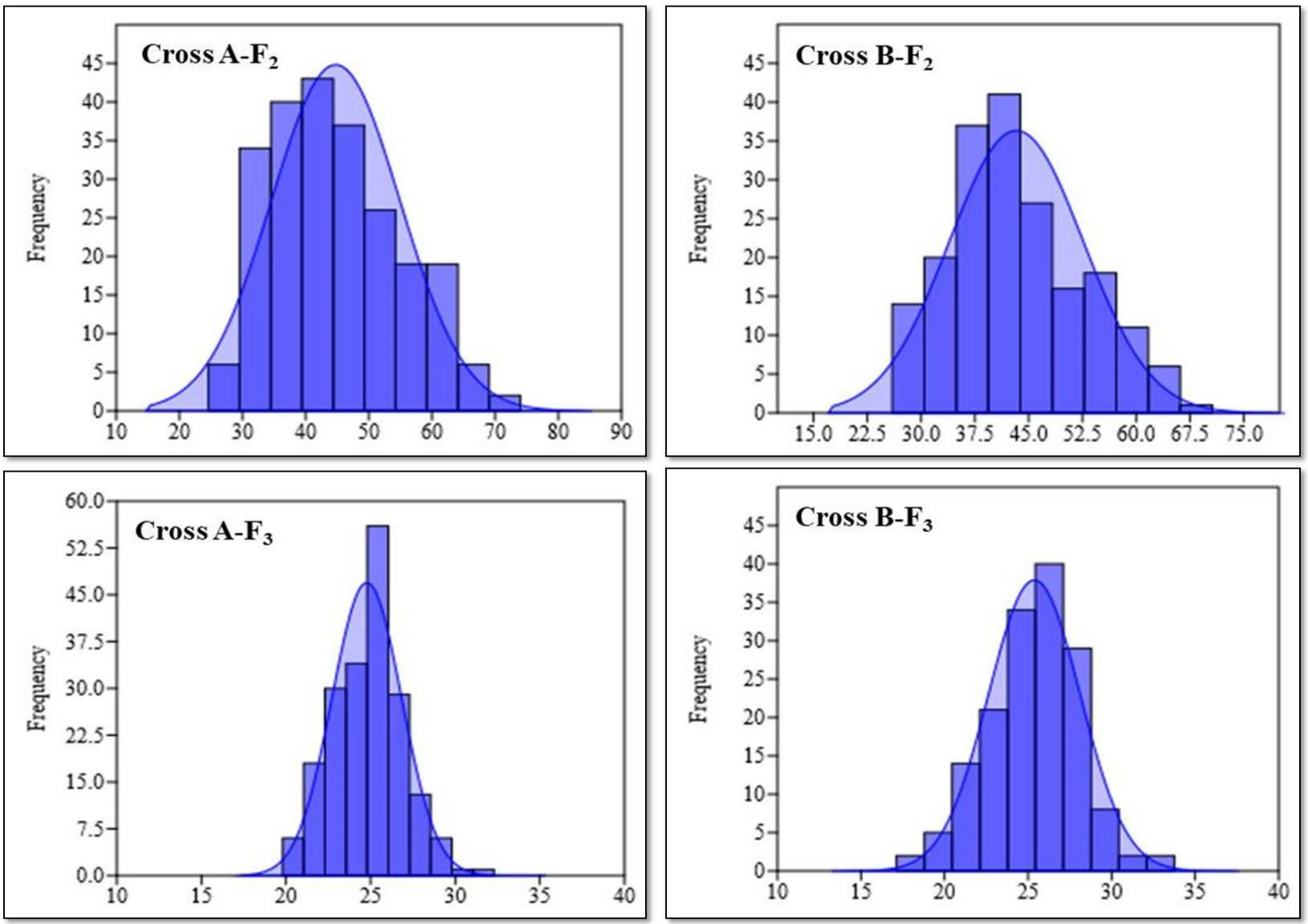
It indicates that over the generation variability in population has decreased due to increase in homozygosity. $\mathrm{InF}_{2}$ generation, cross $\mathrm{A}$ had higher variance (104.00) compared to cross B. It indicates that there is a better chance of identifying high yielding segregants from cross A. These results are in agreement with earlier references (Ajay et al., 2016 and Nandini, et al., 2017).

\section{Character association}

Correlation of characters serves as a measure and forms the basis of selection as it gives direction and magnitude of relationship between the characters studied. Selection for yield will be effective, only when it is considered along with yield attributes rather than relying on yield alone (Dinesh et al., 2017). In cross A, number of branches and 100 seed weight showed strong relationship with plant height while number seeds per pod showed strong relationship with 100 seed weight suggesting that individual plant selections can be practiced in $\mathrm{F}_{3}$ and advanced segregating generations with these characters which could precisely lead to improvement in plant height and 100 seed weight in the later generations (Table 3 and 4). In cross B, number of pods per plant showed strong relationship with number of seeds per pod (Table 4) suggesting that individual plant selections can be practiced in $\mathrm{F}_{3}$ and advanced segregating generations with these characters which could precisely lead to improvement in number of pods per plant and number of seeds per pod in the later generations.

Some characters changed in magnitude of association from generation to generation. For instance association of plant height with number of branches had significant positive association in $\mathrm{F}_{2}$ population and nonsignificant associations in $\mathrm{F}_{3}$ generation of cross B. Similarly, number of branches had significant positive association with 100 grain weight and seed yield per plant in $F_{2}$ population of cross A while they showed nonsignificant associations in $\mathrm{F}_{3}$ generation. Similar results were observed by Ajay et al., (2016) in pigeonpea segregating generations. This kind of shifts in correlation coefficients between generations was attributed to difference in gene complementation of linkage blocks and an indication of unstable nature of breeding population (Preetha and Raveendran, 2008).

It is concluded that yield contributing traits such as number of branches, number of seeds per pod and 100 grain weight are governed by complementary gene action. Since these characters are inter correlated among themselves selection in any one of these traits will result in the improvement of other trait and hence expected to result in increased yield.

\section{References}

Ajay, B. C., Byregowda, M, Veerakumar, G. N, Ganapathy, K. N, Meena, M, Prashanth Babu, H. and Renna, M. 2016. Genetic association and frequency distribution in segregating generations derived from pigeonpea crosses. Indian J. Genet., 76(2): 181186.

Ajay, B. C., Gnanesh, B. N., Ganapathy, K. N., Byregowda, M., Prasad, P. S., Veerakumar, G. N., Venkatesha, S. C., Abdul Fiyaz, R. and Ramya, K. T. 2012. Genetic analysis of yield and quantitative traits in pigeonpea (Cajanus cajan L. Millsp.). Euphytica, 186: 705-714.

Choo, T.M. and E. Reinbergs, 1982. Analysis of skewness and kurtosis for detecting gene interaction in a double haploid population. Crop Science, 22: 231-235.

Dinesh, H.B., Viswanatha, K.P., Lohithaswa, H. C., Pavan, R. and Poonam Singh. 
2017. Variability, correlation and path analysis in $\mathrm{F}_{3}$ generation of cowpea (Vigna unguiculata (L.) Walp) Int. J. Current Micro. Appl. Sci., 6(9): 14201428.

Ehlers, J.D. and Hall, A. E. 1997.Cowpea (Vigna unguiculata L. Walp.) Field Crops Res., 53: 187-204.

Fisher, R.A., 1950. Statistical Methods for Research Workers. 11th Edn., Oliver and Boyd, London, UK., Pages: 75.

Hammer, Ø. Harper, D. A. T. and Ryan, P. D. 2001. PAST: Paleontological statistics software package for education and data analysis. Palaeontologia Electronica, 4: article $49 \mathrm{pp}$.

Nachimuthu, V. V., Robin, S., Sudhakar, D., Raveendran, M., Rajeswari, S. and Manonmani, S. 2014. Evaluation of rice genetic diversity and variability in a population panel by principal component analysis. Indian $J$. Sci.Technol., 7: 555-562.

Nandini, C., Sujata, B., Krishnappa, M., Chandrashekhar Angadi and Prabhakar. 2017. Gene action, genetic parameters and association in segregating populations of two little millet (Panicum miliare L.) crosses. Green Farming3: 523-528.

Pearson, K., 1895. "Notes on regression and inheritance in the case of two parents," Proceedings of the Royal Society of London, 58: 240-242.

Preetha, S. and Raveendren, T. S. 2008.
Genetic appraisal of yield and fibre quality traits in cotton using interspecific $\mathrm{F} 2, \mathrm{~F} 3$ and $\mathrm{F} 4$ populations. Int. J. Integr. Biol., 3: 136-142.

Robson, D.S., 1956. Application of K4 statistics to genetic variance component analysis. Biometrics, 12:433-444.

Samak, A. N. R., Hittalamani, S., Shashidhar, N. and Hanumareddy, B. 2011. Exploratory studies on genetic variability and genetic control for protein and micronutrient content in $\mathrm{F} 4$ and $\mathrm{F} 5$ generations of rice (Oryza sativa L.). Asian J. Plant Sci 10: 376- 379.

Singh, B. B., Chambliss, O. L. and Sharma, B. 1997. Recent advances in cowpea breeding. In: Singh, B. B., Mohan Raj, D. R., Dashiell, K. E., Jackai, L. E. N, (eds)Advances in cowpea research. IITA and Japan International Research Center for Agricultural Sciences (JIRCAS), Ibadan, Nigeria, pp 30-49.

Snedecor, G. W. and Cochron, W. G. 1967. Statistical methods 6th edition Oxford and IBH publishing Co.Pvt. Ltd., New Delhi, India, Pp. 553.

Sulistyowati, Y., Trikoesoemaning Tyas, Sopandie, D., Ardie, S. W. and Nugroho, S., 2015. Estimation of genetic parameters and gene actions of sorghum (Sorghum bicolor (L.) Monech) tolerance to low $\mathrm{P}$ condition. International J. of Ag3:38-46.

\section{How to cite this article:}

Dinesh, H.B., K.P. Viswanatha, H.C. Lohithaswa, R. Pavan and Poonam Singh. 2018. Genetic Association Estimates Using Third and Fourth Degree Statistics in Early Segregating Generations of Cowpea. Int.J.Curr.Microbiol.App.Sci. 7(01): 867-873. doi: https://doi.org/10.20546/ijcmas.2018.701.105 